\title{
Gluten intolerance: Sex- and age-related features
}

\author{
MJ Llorente-Alonso $M D^{1}$, MJ Fernández-Aceñero MD PhD², M Sebastián MD³
}

MJ Llorente-Alonso, MJ Fernández-Aceñero, M Sebastián. Gluten intolerance: Sex- and age-related features. Can J Gastroenterol 2006;20(11):719-722.

OBJECTIVE: Gluten intolerance is an immune-mediated enteropathy associated with gluten-containing foods in genetically susceptible patients. The typical form mainly affecting children shows failure to thrive and/or gastrointestinal symptoms. The adult form is less typical, presenting vague gastrointestinal symptoms, iron deficiency (with or without anemia) or nonspecific serum chemistry abnormalities. The present study aims to analyze clinical and biochemical differences of celiac disease (CD) according to sex and age. PATIENTS AND METHODS: The present study reviewed clinical and biochemical features of patients with suspected CD admitted to the Hospital General of Móstoles (Madrid, Spain) between July 2001 and June 2005. Two hundred fifty-two patients were analyzed, in whom intestinal biopsy was performed due to clinical and/or biochemical abnormalities suggestive of $\mathrm{CD}$. One hundred seventyeight asymptomatic relatives of the affected patients were also included. Overall, 125 patients showed diagnostic features of CD in the intestinal biopsy.

RESULTS: The results confirmed higher prevalence of typical forms of CD in children (67\% in children compared with only $14.3 \%$ in adults). CD seemed to be more frequent in adult women than in men (ratio of women to men 4:1), but it is worth noting that men diagnosed were most often referred with a typical clinical picture, so atypical forms of the disease in men may have been underdiagnosed.

CONCLUSIONS: CD shows atypical features in adults, and physicians must include this disorder in the differential diagnosis of adults with iron deficiency or slight hypertransaminasemia. Increased awareness of the disease and extensive availability of accurate serological tests will lead to improved diagnosis of this disorder, both in children and adults.

Key Words: Age; Atypical forms; Celiac disease; Sex; Transglutaminase antibody

\section{L'intolérance au gluten : Des caractéristiques liées à l'âge et au sexe}

OBJECTIF : L'intolérance au gluten est une entéropathie à médiation immunitaire associée aux aliments renfermant du gluten chez des patients génétiquement susceptibles. La forme classique, qui touche surtout les enfants, entraîne un retard staturopondéral ou des symptômes gastrointestinaux. La forme adulte est moins classique et se manifeste par de vagues symptômes gastro-intestinaux, une carence en fer (accompagnée ou non d'anémie) ou des anomalies chimiques sériques non spécifiques. La présente étude vise à analyser les différences cliniques et biochimiques de la maladie cæliaque (MC) d'après le sexe et l'âge.

PATIENTS ET MÉTHODOLOGIE : La présente étude a consisté à analyser les caractéristiques cliniques et biochimiques de patients atteints d'une MC présumée qui ont été hospitalisés à l'hôpital général de Móstole (à Madrid, en Espagne) entre juillet 2001 et juin 2005. Deux cent cinquante-trois patients ont été analysés, chez qui une biopsie interne a été effectuée en raison d'anomalies cliniques ou biochimiques laissant supposer une MC. Cent soixante-dix-huit parents asymptomatiques des patients atteints ont également participé. Dans l'ensemble, 125 patients ont présenté des caractéristiques diagnostiques de MC d'après la biopsie interne.

RÉSULTATS : Les résultats ont confirmé une plus forte prévalence des formes classiques de MC chez les enfants (67\% par rapport à seulement $14,3 \%$ chez les adultes). La MC semblait plus fréquente chez les femmes que chez les hommes adultes (ratio femmes-hommes de 4:1), mais il convient de souligner que les hommes diagnostiqués étaient plus souvent aiguillés par suite d'un bilan clinique classique. Les formes atypiques de la maladie ont donc été sous-diagnostiquées chez les hommes.

CONCLUSIONS : La MC a des caractéristiques atypiques chez les adultes, et les médecins doivent inclure ce trouble dans le diagnostic différentiel des adultes atteints d'une carence en fer ou d'une légère hypertansaminasémie. Une sensibilisation accrue à la maladie et une grande disponibilité de tests sérologiques précis permettront d'en accroître le diagnostic, tant chez les enfants que chez les adultes.
Celiac disease $(C D)$ is an immune-mediated enteropathy
paused by gluten-containing foods in genetically susceptible
Unionts. Epidemiological studies (1-4) from the European
disorder that can affect $0.5 \%$ to $1 \%$ of the population. However,
in many countries, the incidence seems to be much lower, a fact
that we can attribute both to regional differences in the inci-
dence of the disease and also to the underdiagnosis of the disor-
der, which can show many different clinical pictures $(5-8)$. In
recent years, the advances in serological tests for diagnosis have
allowed for improved detection of atypical and silent variants of
the disease $(1,9)$.
The aim of the present study is to describe the age- and sexrelated differences in the clinical manifestations of CD.

\section{Study population}

\section{PATIENTS AND METHODS}

Between July 2001 and June 2005, 7298 patients were referred to the laboratory at the Hospital General of Móstoles (Madrid, Spain) for determination of immunological markers of CD. Most of these patients $(61.7 \%)$ were referred by the department of pediatrics, $16.8 \%$ by the department of medicine, $16.7 \%$ by the gastroenterology department and $4.4 \%$ by other departments. 
TABLE 1

Demographic characteristics of the study population

\begin{tabular}{|c|c|c|c|c|}
\hline \multirow[b]{2}{*}{ Diagnosis } & \multirow[b]{2}{*}{ Age, years } & \multicolumn{2}{|c|}{ Sex } & \multirow{2}{*}{$\begin{array}{l}\text { Female to } \\
\text { male ratio } \\
(: 1)\end{array}$} \\
\hline & & Female, $\mathbf{n}$ & Male, $\mathbf{n}$ & \\
\hline \multirow[t]{3}{*}{$C D$ group $(n=125)$} & $<3$ & 36 & 18 & 2.00 \\
\hline & $3-14$ & 23 & 13 & 1.77 \\
\hline & $>14$ & 28 & 7 & 4.00 \\
\hline Overall & & $87(69.6 \%)$ & $38(30.4 \%)$ & 2.28 \\
\hline \multirow[t]{3}{*}{ Control group $(n=127)$} & ) $<2$ & 14 & 11 & 1.27 \\
\hline & $3-14$ & 9 & 11 & 0.82 \\
\hline & $>14$ & 46 & 36 & 1.27 \\
\hline Overall & & $69(54.3 \%)$ & $58(45.7 \%)$ & 1.19 \\
\hline Risk groups (relatives) & & $91(51.1 \%)$ & $87(48.9 \%)$ & 1.04 \\
\hline CD cases & & 10 & 4 & 2.50 \\
\hline
\end{tabular}

$C D$ Celiac disease

From this cohort of patients, all patients fulfilling inclusion and exclusion criteria $(n=252)$ were analyzed; the inclusion criteria included all patients in whom highly sensitive serum markers for $\mathrm{CD}$ were perfomed and histological analysis of small intestine biopsy. The only exclusion criterion was immunoglobulin $\mathrm{A}$ deficiency. The results of the intestinal biopsy and the immunological markers of the CD were analyzed blindly and independently.

The patients were classified into two different groups: group I (125 patients diagnosed with CD via intestinal biopsy) and group II (127 patients with clinical and/or immunological suspicion of CD whose intestinal biopsy was normal). The latter is considered to be the control group without $\mathrm{CD}$. One hundred seventy-eight asymptomatic first-degree relatives of CD patients were included. In this group, intestinal biopsy was only performed when the immunological tests were abnormal.

\section{Clinical picture}

Patients were classified into two groups according to their presentation. The typical pattern of $\mathrm{CD}$ was comprised of patients with gastrointestinal (GI) symptoms and/or failure to thrive. The atypical pattern of disease was extraintestinal symptoms (iron deficiency associated or not associated with anemia and hypertransaminasemia) and also asymptomatic individuals, either relatives of patients or those belonging to groups at risk of disease (diabetics and Down syndrome).

When one patient showed more than one sign or symptom after initial presentation, they were classified according to the presenting symptom.

\section{Serological and other biochemical markers}

A serum specimen was obtained in all patients for determination of immunological markers of $\mathrm{CD}$ and other biochemical parameters. The level of immunoglobulin A human tissue transglutaminase antibodies was determined by ELISA and the antibody concentration was expressed in $\mathrm{U} / \mathrm{mL}$.

The levels of aspartate aminotransferase (AST), alanine aminotransferase (ALT) and ferritin were measured using a Hitachi Modular (Roche Diagnostics, Spain). Iron deficiency was defined as a ferritin level less than $15 \mu \mathrm{g} / \mathrm{L}$.

\section{Statistical analysis}

A descriptive analysis of all the variables was performed, and frequency, median and percentile $\left(\mathrm{P}_{5-95}\right)$ values were included. Differences between quantitative variables were assessed with the
TABLE 2

Clinical presentation of celiac disease (CD) distributed by sex and age

\begin{tabular}{|c|c|c|c|c|c|c|}
\hline \multirow[b]{2}{*}{ Age, years } & \multicolumn{3}{|c|}{ Female patients } & \multicolumn{3}{|c|}{ Male patients } \\
\hline & $<3$ & $3-14$ & $>14$ & $<3$ & $3-14$ & $>14$ \\
\hline Group, n (\%) & n (\%) & n (\%) & n (\%) & n (\%) & n (\%) & n (\%) \\
\hline $\begin{array}{c}\text { Typical CD } \\
65(52)\end{array}$ & $28(78)$ & $10(43)$ & $3(11)$ & $14(77)$ & $8(61)$ & $2(29)$ \\
\hline Overall & & $41(63)$ & & & $24(37)$ & \\
\hline $\begin{array}{c}\text { Atypical CD } \\
60(48)\end{array}$ & $8(22)$ & $13(56)$ & $25(89)$ & $4(22)$ & $5(38)$ & $5(71)$ \\
\hline Overall & & $46(76.6)$ & & & $14(23.3)$ & \\
\hline $\begin{array}{l}\text { Total, } \\
125 \text { (100) }\end{array}$ & $36(100)$ & $23(100)$ & $28(100)$ & $18(100)$ & $13(100)$ & $7(100)$ \\
\hline
\end{tabular}

Mann-Whitney U test, and qualitative variables were compared with $\chi^{2}$ with Yates' correction.

\section{RESULTS}

The demographic characteristics of the patients are summarized in Table 1. The CD group included 87 females $(69.6 \%)$ and 38 males (30.4\%). Ninety patients (59 female and 31 male) were younger than 15 years of age and 35 were adults (28 women and seven men).

The asymptomatic relatives group included 53 fathers, 55 mothers, seven sons and daughters of the patients, and 61 brothers or sisters; two of them were twins of patients with CD. In this group, 14 cases of CD were diagnosed with intestinal biopsy (8\%), 10 in female patients and four in male patients. Of these CD patients, nine were children and five were adults; their relationship with the patient was one father, two mothers, seven brothers or sisters, two sons and daughters, and two twins.

The rate of CD was twice as high in women than in men for the overall population (the female to male ratio was 2.3), for the pediatric group (1.97) and for the relatives (2.5). However, in adults this ratio was much higher, reaching $4: 1$.

The rate of diagnosis tended to decrease with age, and as expected, the age group in which new cases of CD were most often diagnosed were in children under three years of age. Sixty-five cases $(52 \%)$ of typical CD were found, but it is worth noting that 60 patients (48\%) showed atypical manifestations of CD. Table 2 summarizes the clinical picture for the different age and sex groups. The classical clinical picture is significantly more prevalent in children than in adults $(92.3 \%$ versus $7.7 \%$; $\mathrm{P}<0.001$ ). If we take into consideration only patients with atypical forms of $\mathrm{CD}(\mathrm{n}=60)$, the age distribution is similar, $50 \%$ (30 of 60 ) were children and $50 \%$ (30 of 60 ) were adults.

In terms of sex, male patients tended to show more frequently classical forms of CD (24 of 38 [63.2\%] patients) while women (41 of 87 [47\%] patients) showed an almost equal distribution. Nevertheless, the typical forms were found almost exclusively in children (38 of 63) and only in three adult women. Correspondingly, atypical CD mainly affects female patients older than 14 years of age ( 25 of 28; 89\%). In male patients, similar analysis cannot be performed due to the small number of adults participating in the study.

For both sexes, the incidence of typical CD tends to decrease with age and this clinical form represents $78 \%$ of cases in children younger than three years of age for both sexes; $43 \%$ in 


\section{TABLE 3}

Signs and/or symptoms of celiac disease (CD) at diagnosis

\begin{tabular}{lccccc}
\hline $\begin{array}{l}\text { Signs and/or } \\
\text { symptoms }\end{array}$ & Diagnosis & $\mathbf{n}$ & $\begin{array}{c}\text { CD patients with } \\
\text { a sign/symptom, } \\
\mathbf{n}(\%)\end{array}$ & $\begin{array}{c}\text { Children, Adults, } \\
\mathbf{n}(\%)\end{array}$ & $\mathbf{n}(\%)$ \\
\hline $\begin{array}{l}\text { Gastrointestinal } \\
\text { problems/failure }\end{array}$ & Non-CD & 64 & $64(46.3)$ & $59(65.5)$ & $5(14.3)$ \\
to thrive, n=138 & & & & & \\
$\begin{array}{l}\text { Iron deficiency with } \\
\text { or without anemia, }\end{array}$ & Non-CD & 15 & $15(39.5)$ & $7(7.7)$ & $8(22.9)$ \\
$n=38$ & & & & & \\
$\begin{array}{l}\text { Others, } \\
n=47\end{array}$ & CD & 26 & $26(56.5)$ & $12(13.3) 14(40)$ \\
$\begin{array}{l}\text { CD in risk groups, } \\
n=206\end{array}$ & Non-CD & 21 & & & \\
\hline
\end{tabular}

Others include hypertransaminasemia, endocrine diseases, infertility and aphthous stomatitis. Risks groups are relatives of CD patients, and patients with diabetes mellitus type I or Down Syndrome

female patients between three and 14 years of age versus $61 \%$ for male patients in the same age group; and $11 \%$ and $29 \%$ for females and males over 14 years, respectively.

Table 3 compares the presenting symptoms of CD. Significant differences in clinical presentation were found according to age $(\mathrm{P}<0.001)$. Failure to thrive or low weight, and GI symptoms were more prevalent in children (almost $65.5 \%$ of all cases), while in adults, the predominant findings were abnormalities in the hepatic function tests $(40 \%)$, followed by iron deficiency $(22.9 \%)$, with a similar frequency in other risk groups $(22.8 \%)$.

Table 4 summarizes the abnormalities in the serum levels of transaminases and ferritin. Fifty-seven per cent of CD patients showed a significant increase in serum levels of AST and 38.3\% in levels of ALT, compared with 23\% in levels of AST and 11\% ALT in the control group $(\mathrm{P}<0.001)$. There were no significant differences in the transaminases levels between both sexes, but children tended to show a median ALT value slightly higher than adults ( $40 \mathrm{U} / \mathrm{L}$ versus $31 \mathrm{U} / \mathrm{L} ; \mathrm{P}=0.07)$, while $A S T$ values were significantly higher in adults than in children $(36 \mathrm{U} / \mathrm{L}$ versus $26 \mathrm{U} / \mathrm{L} ; \mathrm{P}=0.009$ ).

Thirty-nine per cent of CD patients had low ferritin levels compared with $22 \%$ of the controls $(\mathrm{P}<0.014)$. There were no differences in ferritin levels according to sex. Nevertheless, the median ferritin level was significantly lower in adults with $C D$ than in children (less than $15 \mu \mathrm{g} / \mathrm{L}$ versus $20 \mu \mathrm{g} / \mathrm{L} ; \mathrm{P}<0.001$ ), a fact that could be attributed to the increased frequency of low ferritin levels in adult women compared with younger girls $(60 \%$ versus $31.4 \% ; \mathrm{P}<0.01$ ).

\section{DISCUSSION}

The aim of the present study was to prospectively define the clinical features of $\mathrm{CD}$ and possible differences related to either sex or age. In the present study, the prevalence of $\mathrm{CD}$ was twice as high in women than in men. These results were in complete accordance to those reported by Bardella et al (5). However, Green et al (10) used CD screening survey results taken from the general population and blood donors, which indicated that CD distribution was similar in men and women. We feel that this apparent contradiction may indicate that most studies performed in symptomatic patients are biased by population selection. Our
TABLE 4

Aspartate aminotransferase (AST), U/mL; alanine aminotransferase (ALT), $U / \mathrm{mL}$ and ferritin, $\mu \mathrm{g} / \mathrm{L}$, levels by age and sex in controls and celiac disease (CD) patients

\begin{tabular}{cccccccc}
\hline & & & \multicolumn{5}{c}{ CD patients } \\
\cline { 3 - 7 } & $\begin{array}{c}\text { Control } \\
\mathbf{n = 1 2 6}\end{array}$ & $\begin{array}{c}\mathbf{C D} \\
\mathbf{n = 1 2 5}\end{array}$ & $\begin{array}{c}\text { Females } \\
\mathbf{n = 8 7}\end{array}$ & $\begin{array}{c}\text { Males } \\
\mathbf{n = 3 8}\end{array}$ & $\begin{array}{c}\text { Children } \\
\mathbf{n = 9 0}\end{array}$ & $\begin{array}{l}\text { Adults } \\
\mathbf{n = 3 5}\end{array}$ \\
\hline ALT $\left(\mathrm{P}_{50}\right)$ & 21 & $37^{*}$ & 36 & 37 & 40 & $31^{* *}$ \\
$\left(\mathrm{P}_{5-95}\right)$ & $13-58$ & $20-74$ & $18-90$ & $23-76$ & $21-73$ & $13-133$ \\
AST $\left(\mathrm{P}_{50}\right)$ & 19 & $29^{*}$ & 29 & 29 & 26 & $36^{*}$ \\
$\left(\mathrm{P}_{5-95}\right)$ & $10-64$ & $14-74$ & $14-74$ & $15-83$ & $13-70$ & $16-115$ \\
Ferritin $\left(\mathrm{P}_{50}\right)$ & 33 & $20^{*}$ & 21 & 16 & 20 & $<15^{*}$ \\
$\left(\mathrm{P}_{5-95}\right)$ & $<15-224$ & $<15-54$ & $<15-53$ & $<15-145$ & $<15-66$ & $<15-34$ \\
\hline${ }^{*} P<0.01 ;{ }^{* *} P=0.07$ & & & & &
\end{tabular}

results suggest that the sex difference in CD incidence could be real for the number of patients studied on clinical and/or immunological suspicion of $\mathrm{CD}$, and is almost equivalent for both sexes ( $46 \%$ of male patients versus $54 \%$ of females patients in the control group and $48.9 \%$ versus $51.1 \%$, respectively, in the asymptomatic relatives group); confirmation of $\mathrm{CD}$ with biopsy doubled in women compared with men. Nevertheless, we cannot consider this fact surprising, because many diseases with an autoimmune pathogenesis show a higher prevalence in women.

The prevalence of $\mathrm{CD}$ in asymptomatic relatives of $\mathrm{CD}$ patients has been estimated by some reports $(5,11)$ to be between $5 \%$ and $10 \%$. Our prevalence was $8 \%$, therefore corroborating previous results on the issue.

Some authors have reported that the diagnosis of $\mathrm{CD}$ increases with age $(5,10,12)$. However, in the present study, the frequency of $\mathrm{CD}$ diagnosis decreased with age. This apparent contradiction can be attributed to the fact that in areas such as Móstoles, Spain, CD is underdiagnosed, mainly in adults and men. To support this view we can mention the high prevalence of the typical forms of CD in men (63.2\%) in our study and the unexpected difference in the frequency of the disease between both sexes in adults (four times higher in women than in men). The main conclusions of our work are atypical, and silent forms of the disease go undiagnosed in adults, especially in men. It seems that CD is only suspected in adult men when the fullblown classical picture of the disease is found; despite this, the clinical presentation is rather infrequent in this age group according to the literature.

There are not many data regarding prevalence of $\mathrm{CD}$ among children with typical or atypical forms of the disease. In the present study, the rate of $\mathrm{CD}$ among patients presenting with GI symptoms and/or abnormalities in weight or height was $46.3 \%$. This contrasts with the situation in adults, in whom GI symptoms are much less frequent $(14.3 \%)$. Failure to thrive or weight loss, associated or not associated with GI symptoms, was the main presenting symptom in children $(54.7 \%$ in the present study). No adults reported weight abnormalities because they gave less importance to this symptom.

The most frequent presenting signs in adult patients were hypertransminasemia and iron deficiency. It has been described that $15 \%$ to $50 \%$ of adults with atypical CD show increased levels of transaminasemia, and also, $95 \%$ of cases of unexplained increases in transaminases could be due to silent CD (13-15). In the present study, $57 \%$ of CD patients showed a moderate ALT increase compared with $23 \%$ of the controls $(\mathrm{P}<0.001)$, and this 
increase was significantly higher in children than in adults (58.6\% versus $41.4 \% ; \mathrm{P}<0.038)$. AST levels were increased in $38 \%$ of CD patients compared with $11 \%$ of the controls $(\mathrm{P}<0.001)$, but in this case, the increase was more important in adults than in children ( $55.2 \%$ versus $44.8 \% ; \mathrm{P}=0.02)$.

Iron deficiency associated or not associated with anemia was one of the most frequent signs found in adults (16-20), and our results are consistent with this finding $-39 \%$ of the patients showed low serum levels of ferritin versus $22 \%$ of the controls $(\mathrm{P}<0.014)$. Iron deficiency was more prevalent in adult women than in men $(60 \%$ versus $43 \%)$, but we considered this difference to be biased by the small number of men included in the study. However, in children, iron deficiency seemed to be rather infrequent, at least as an isolated finding, and only two children were studied solely on this sign.

We consider it noteworthy that the median time since symptom appearance in adults was at least two to five years, compared with only a few months in children, a fact already stated by other authors $(10,21)$. If suspected in this age group, the wider availability of testing of sensitive and accurate serum markers of CD, especially human tissue transglutaminase antibodies, could allow for an easier and quicker diagnosis of this disease $(1,8,21,22)$.

\section{REFERENCES}

1. Maki M, Mustalahti K, Kokkonen J, et al. Prevalence of celiac disease among children in Finland. N Engl J Med 2003;348:2517-24.

2. Hoffenberg EJ, Mackenzie T Barriga KJ, et al. A prospective study of the incidence of childhood celiac disease. J Pediatr 2003;143:308-14.

3. Cilleruelo MaL, Román E, Jimenez J, et al. Enfermedad celíaca silente: Explorando el iceberg en población escolar. An Esp Pediatr 2002;57:321-6.

4. Catassi C, Fabiani E, Ratsch IM, et al. The coeliac iceberg in Italy. A multicentre antigliadin antibodies screening for coeliac disease in school-age subjects. Acta Paediatr Suppl 1996;412:29-35.

5. Bardella MT, Fredella C, Saladino V, et al. Gluten intolerance: Gender-and age-related differences in symptoms. Scand J Gastroenterol 2005;40:15-9.

6. Fasano A, Catassi C. Current approaches to diagnosis and treatment of celiac disease: An evolving spectrum. Gastroenterology 2001;120:636-51

7. Green PH. The many faces of celiac disease: Clinical presentation of celiac disease in the adult population. Gastroenterology 2005;128:S74-8.

8. Hill ID, Dirks MH, Liptak GS, et al. Guideline for the diagnosis and treatment of celiac disease in children: Recommendations of the North American Society for Pediatric Gastroenterology, Hepatology and Nutrition. J Pediatr Gastroenterol Nutr 2005;40:1-19.

9. Rostom A, Dube C, Cranney A, et al. The diagnostic accuracy of serologic tests for celiac disease: A systematic review. Gastroenterology 2005;128:S38-46.

10. Green PHR, Stavropoulos SN, Panagi SG, et al. Characteristics of adult celiac disease in the USA: Results of a national survey. Am J Gastroenterol 2001;96:126-31.

11. Pittschieler K, Gentili L, Niederhofer H. Onset of coeliac disease: A prospective longitudinal study. Acta Paediatr 2003;92:1149-52.

12. Mulder CJ, Cellier C. Coeliac disease: Changing views. Best Prac Res Clin Gastroenterol 2005;19:313-21.

13. Volta U, Granito A, De Franceschi L, Petrolini N, Bianchi FB. Anti tissue transglutaminase antibodies as predictors of silent coeliac
We must also consider the fact that even vague symptoms in adults improve dramatically with a gluten-free diet, and patients have described improvements in their overall quality of life with $\operatorname{diet}(10)$.

Almost $23 \%$ of CD adults belonged to risk groups (either relatives or patients with diabetes mellitus or Down syndrome); these data are also consistent with those reported by other authors $(22 \%$ in the study by Green et al [10]). Serological screening would be especially important in the groups at risk of CD (23-24).

\section{CONCLUSION}

The results of the present study confirm clinical and laboratory differences in CD between children and adults, and also between both sexes. We feel that CD is widely underdiagnosed in our environment, mainly in adults and primarily in men. Although this low rate of diagnosis in adults can be attributed to the little importance given to the general vague symptoms of these patients, clinicians should begin to include CD in the differential diagnosis of hypertransminasemia and iron deficiency in both children and adults, and stop considering CD as a disease found exclusively in children. disease in patients with hypertransaminasemia of unknown origin. Dig Liver Dis 2001;33:420-5.

14. Gonzalez-Abraldes J, Sanchez Fueyo A, Bessa X, et al. Persistent hypertransaminasemia as the preventing feature of celiac disease. Am J Gastroenterol 1999;94:1095-7.

15. Carroccio A, Giannitrapani L, Soresi M, et al. Guinea pig transglutaminase inmunolinked assay does not predict coeliac disease in patients with chronic liver disease. Gut 2001;49:506-11.

16. Farrell RJ, Kelly CP. Celiac sprue. N Engl J Med 2002;346:180-8.

17. Bottaro G, Cataldo F, Rotolo N, Spina M, Corazza R. The clinical pattern of subclinical/silent celiac disease: An analysis on 1026 consecutive cases. Am J Gastroenterol 1999;94:691-6.

18. Johnston SD, Watson RG, McMillan SA, Sloan J, Love AH. Prevalence of coeliac disease in Northern Ireland. Lancet 1997;350:1370.

19. Carroccio A, Iannitto E, Cavataio F, et al. Sideropenic anemia and celiac disease: One study, two points of view. Dig Dis Sci 1998;43:673-8.

20. Hershko C, Hoffbrand AV, Keret D, et al. Role of autoimmune gastritis, Helicobacter pylori and celiac disease in refractory or unexplained iron deficiency anemia. Haematologica 2005;90:585-95.

21. Favre G, Grunenberger F, Wurtz E, et al. Adult celiac disease: Importance of delay to diagnosis. Presse Med 2000;29:1973-7.

22. Llorente MJ, Sebastian M, Fernandez-Aceñero MJ, Serrano G, Villanueva S. IgA antibodies against tissue transglutaminase in the diagnosis of celiac disease: Concordance with intestinal biopsy in children and adults. Clin Chem 2004;50:451-3.

23. Buysschaert M, Tomasi JP, Hermans MP. Prospective screening for biopsy proven coeliac disease, autoimmunity and malabsorption markers in Belgian subjects with Type I diabetes. Diabet Med 2005;22:889-92.

24. Annibale B, Severi C, Chistolini A, et al. Efficacy of gluten-free diet alone on recovery from iron deficiency anemia in adult celiac patients. Am J Gastroenterol 2001;96:132-7. 


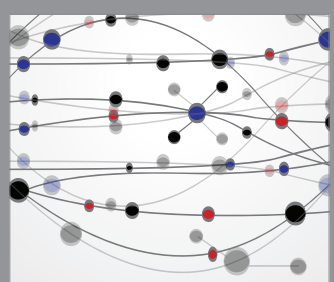

The Scientific World Journal
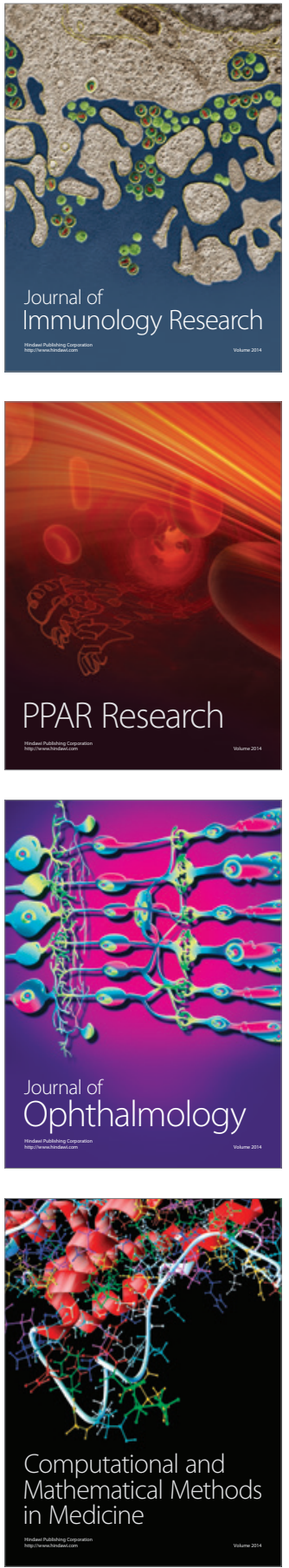

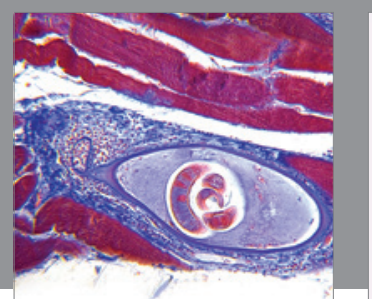

Gastroenterology Research and Practice

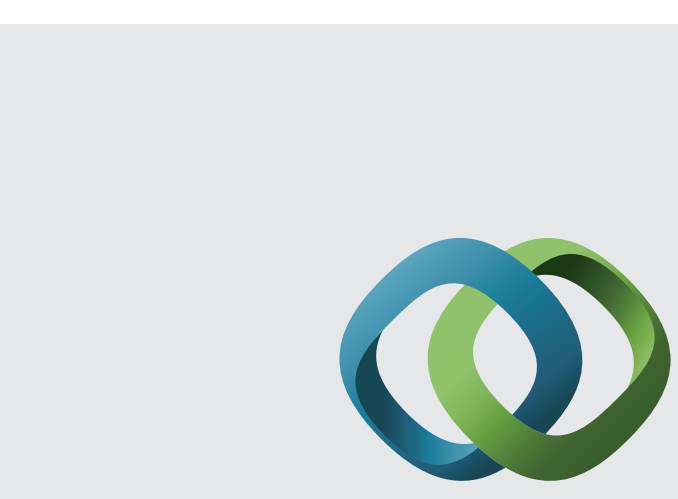

\section{Hindawi}

Submit your manuscripts at

http://www.hindawi.com
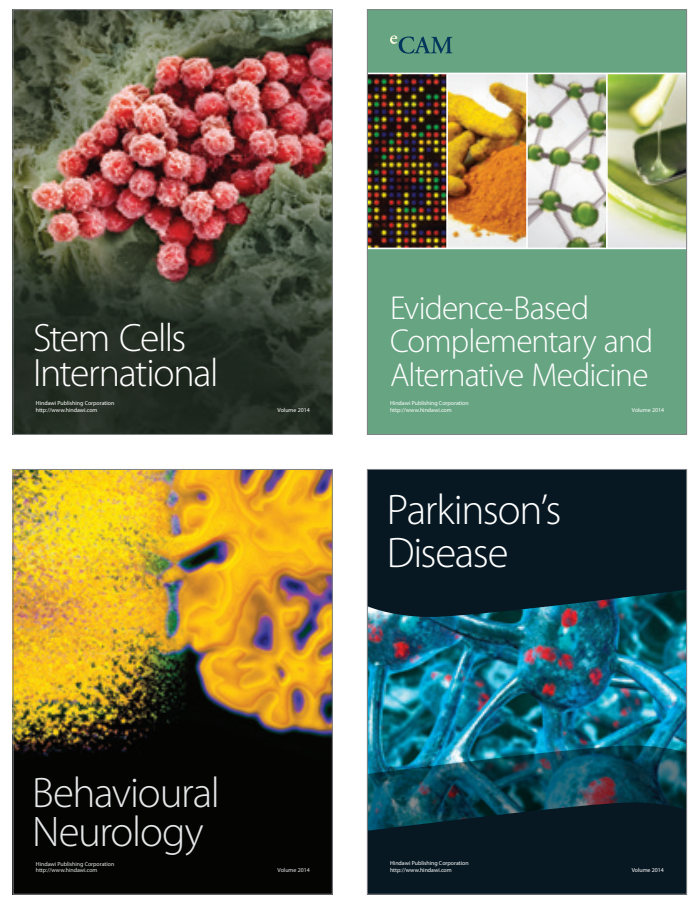
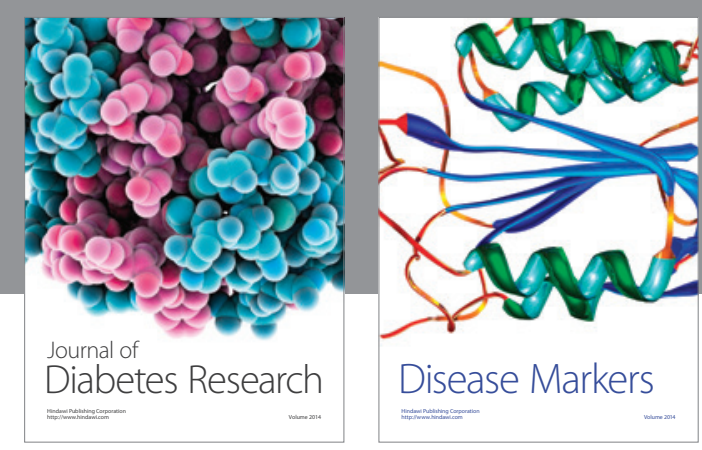

Disease Markers
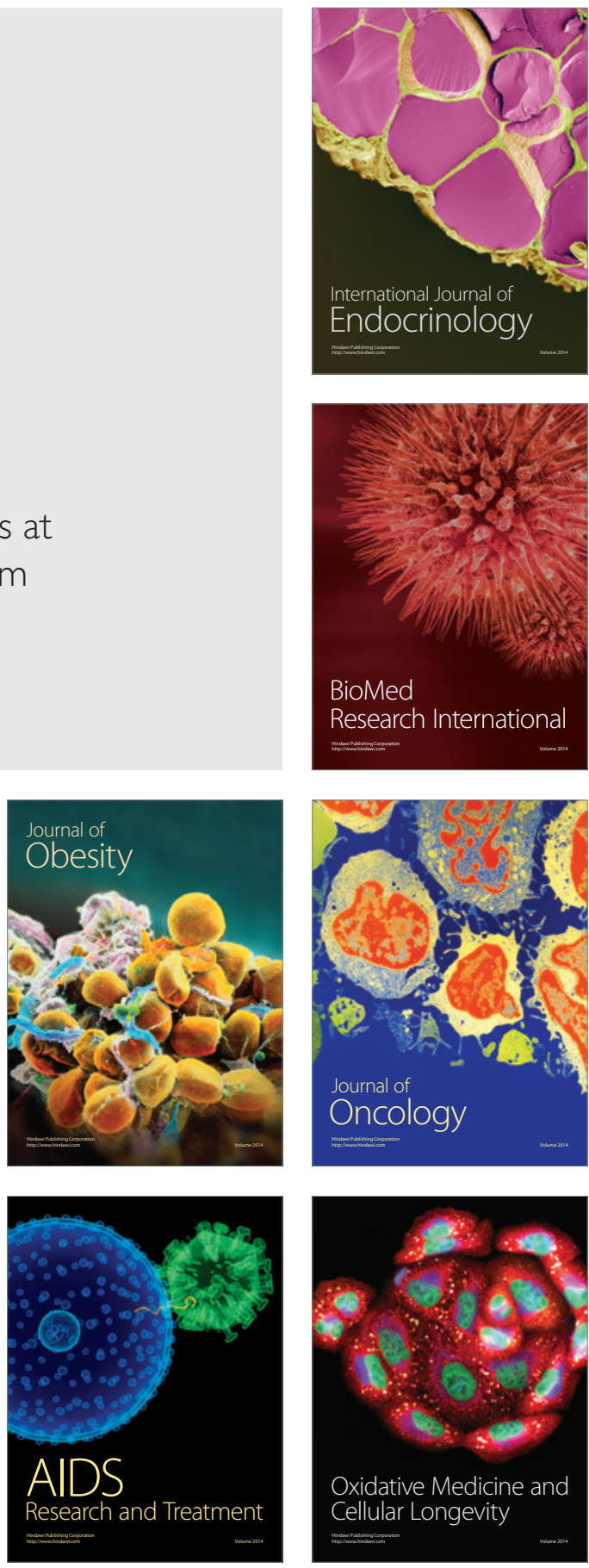